\title{
REGENERATION OF SENSORY-MOTOR SYNAPSES IN THE SPINAL CORD OF THE BULLFROG ${ }^{1}$
}

\author{
DINAH W. Y. SAH AND ERIC FRANK ${ }^{2}$
}

Department of Neurobiology, Harvard Medical School, Boston, Massachusetts 02115

Received January 6, 1984; Revised May 4, 1984; Accepted May 10, 1984

\begin{abstract}
Sensory fibers innervating muscles in the arm of the bullfrog form specific patterns of monosynaptic connections with motoneurons in the spinal cord. We show here that these normal patterns are re-established after interruption of the second dorsal root (DR2) in tadpoles and postmetamorphic frogs. DR2 was either cut or crushed, and 2 to 8 months later the extent and specificity of regeneration were assessed anatomically and physiologically. Horseradish peroxidase labeling of DR2 showed that sensory afferents had regenerated back into the spinal cord to form local arborizations, as in the normal adult. However, few long-tract fibers in the dorsal columns regenerated. Intracellular recording from different classes of motoneurons at the level of DR2 revealed that triceps muscle sensory afferents had regenerated to form functionally appropriate synapses. As in the normal adult, stimulation of the triceps nerves elicited larger monosynaptic EPSPs in triceps motoneurons than in non-triceps motoneurons. Thus, in the central nervous system of the bullfrog, specific monosynaptic connections are re-formed within the region of local regeneration.
\end{abstract}

Regeneration of synaptic connections within the central nervous system (CNS) occurs only to a limited extent. One of the major problems in many systems is that lesioned axons do not grow back to their original target area. For example, transection of the mammalian spinal cord results in permanent loss of anatomical continuity (Puchala and Windle, 1977; Gearhart et al., 1979). Regenerating axons do not-elongate across the lesion site. One possible explanation is that central neuroglial cells are much less conducive to axonal elongation than are Schwann cells (Stensaas et al., 1979; Perkins et al., 1980; Richardson et al., 1980, 1982; David and Aguayo, 1981). Because of the difficulty in achieving axonal regrowth, comparatively little is known about whether appropriate synapses would be formed at the original target area.

We have studied the regeneration of monosynaptic sensorymotor connections in the brachial spinal cord of the bullfrog after dorsal root section. In this system, synaptic contacts are located in close proximity to the dorsal root entry zone so that lesioned fibers need not regenerate over long distances within the CNS to reach their original target area. Synaptic reconnection can be assessed directly by recording from motoneurons

\footnotetext{
${ }^{1}$ Sonal Jhaveri participated in early experiments on regeneration in tadpoles. We thank Y. Pearlson and E. Wu for histological assistance, and Drs. S. LeVay and C. Smith for comments on the manuscript. This work was supported by National Institutes of Health Grants NS 14451 and NS 20859, the Paralyzed Veterans of America, and the William Randolf Hearst Foundation (E. F.), and by a predoctoral fellowship from the National Science Foundation (D. S.).

${ }^{2}$ To whom correspondence should be sent, at his present address: Department of Neurobiology and Physiology, Northwestern University, 2153 Sheridan Road, Evanston, IL 60201.
}

intracellularly while stimulating various sensory nerves. Moreover, the specificity of these new connections can be tested since muscle sensory afferents normally project differentially to synergistic versus antagonistic motoneurons. We report here that triceps sensory afferents re-establish their normal specific pattern of connections with brachial motoneurons in the spinal cord.

A preliminary account of these results has appeared in abstract form (Frank et al., 1982), and some of the anatomical findings have recently been confirmed (Liuzzi and Lasek, 1983).

\section{Materials and Methods}

Bullfrog (Rana catesbeiana) tadpoles (larval stages XIV through XXIV, staged according to the criteria of Taylor and Kollros (1946)) or juveniles ( 3 to $4 \mathrm{~cm}$ in length) were anesthetized by immersion in $0.1 \%$ tricaine methanesulfonate. The second dorsal root (DR2), which contains all of the forelimb sensory afferents, was exposed for unilateral lesion by a dorsal laminectomy and was cut or crushed close to its entry point into the spinal cord. Each crush was performed twice, for $5 \mathrm{sec}$ each time, with forceps ground flat for $1 \mathrm{~mm}$; the root became transparent in the region of the crush and was most often nearly severed by the procedure. The wounds were sutured and the animals were allowed to recover. All animals showed a complete absence of sensation in their affected forelimbs and used them abnormally for at least several weeks.

Two to 8 months later, the regeneration was assessed physiologically and anatomically. For the tadpole group, this period of time was sufficient to allow metamorphosis to occur. Behavioral recovery was assessed in two ways: forelimb withdrawal in response to pinch and correct placement of the forelimb during landing. The position of the limb during landing was determined in 8 to 10 trials. Afterwards, the animal was anesthelized in ice water, decapitated, and perfused intracardially with cold saline. The subsequent dissection procedure was the same as that described by Frank and Westerfield (1982). The preparation consisted of the longitudinally hemisected spinal cord with intact brachial nerve branches. The nerves prepared for stimulation included 
the branches to the internal, external, and medial heads of the triceps brachii muscles, the nerves supplying the subscapularis and pectoralis muscles, the ulnar and radial nerves which innervate all of the muscles in the forearm and hand, and the two superior cutaneous nerve branches that exit from the ulnar and radial nerves just above the level of the elbow (ramus cutaneous superior of nervus ulnaris, and ramus cutancus superior of nervus radialis (Ecker, 1889)). The bath temperature in the recording chamber was maintained at about $14^{\circ} \mathrm{C}$. The preparation was perfused with fresh, oxygenated saline of the following composition (millimolar concentration): $\mathrm{Nu}^{+}, 116 ; \mathrm{K}^{+}, 2 ; \mathrm{Ca}^{2+}, 1.8 ; \mathrm{Cl}^{-}$, 122; glucose, 15; HEPES buffer, 5 at pH 7.2. Standard electrophysiological techniques were employed (Frank and Westerfield, 1982). Motoneurons were impaled with microelectrodes filled with $0.5 \mathrm{M}$ potassium citrate or $2 \mathrm{M}$ potassium methylsulfate, with $0.5 \%$ fast green dye added to make the electrode tip visible. Triceps, ulnaris, radialis, subscapularis, and pectoralis motoneurons were identified by antidromic stimulation. Synaptic potentials, elicited by electrical stimulation of individual muscle nerves with suction electrodes, were recorded in cells whose resting potentials were at least $40 \mathrm{mV}$. Individual traces were averaged using either a signal averager (Dagan Corp.) or a PDP 11/23 computer (BASIC/23 software written by Dr. Gary Yellen). After the microelectrode was withdrawn from the cell, extracellular field potentials were recorded and subtracted digitally from the intracellular record.

The specificity of sensory-motor connections was assessed in two ways. First, the latency of synaptic inputs from cutaneous and muscle sensory axons was compared. Spindle afferents make short-latency, monosynaptic connections with motoneurons, whereas cutaneous fibers provide only longer-latency, polysynaptic inputs. Second, we measured the ability of regenerating muscle sensory afferents to discriminate among different types of motoneurons by comparing the ratio of triceps muscle sensory EPSPs in triceps versus non-triceps motoneurons. Normally, triceps sensory axons always produce larger monosynaptic EPSPs in triceps motoneurons than in several different types of nontriceps motoneurons (Frank and Westerfield, 1982). The measurements of triceps sensory input to synergistic (e.g., medial triceps sensory input onto internal/external triceps motoneurons) and unrelated motoneurons are straightforward since the muscle nerve can be stimulated so that all myelinated sensory axons are activated. However, homonymous sensory inputs (e.g., medial triceps sensory input onto medial triceps motoneurons) are difficult to measure for two reasons. First, sensory and motor axons have similar electrical thresholds, so that all the sensory axons cannot be activated wthout contaminating the recording with the antidromic impulse. Second, homonymous motoneurons are electrically coupled with each other. Thus, even below the threshold for antidromic activation of the cell being studied, the synaptic input from sensory cells is contaminated by electrical coupling potentials from the antidromic impulses in other motoneurons. These problems have been discussed in detail elsewhere (Frank and Westerfield, 1982). Because of these difficulties, we have not included measurements of homonymous sensory-motor connections. Internal and external triceps nerves were always stimulated together since the muscles appear to be functionally equivalent (see Westerfield and Frank, 1982; Lichtman and Frank, 1984).

The latencies of EPSP components were measured with respect to the time of peripheral nerve stimulation. Only components with latencies less than or equal to $6.5 \mathrm{msec}$ were classified as monosynaptic. This upper boundary is slightly longer than that used previously $(5.5$ msec, Frank and Westerfield, 1982). Because the smaller EPSPs in animals with regenerated dorsal roots are probably produced by a smaller number of sensory axons than normal, one would expect the latency of some of these EPSPs to be nearly as long as the longest single unit latency (up to $7.0 \mathrm{msec}$; see Lichtman and Frank, 1984). However, the demonstration that regenerated connections are specific does not depend critically on the choice of the upper latency boundary. For example, if the upper boundary is taken at 5.5 msec instead of 6.5 msec, the specificity index (see "Results") for all animals with regenerated dorsal roots only falls from 0.74 to 0.71 .

Amplitudes of monosynaptic components of EPSPs were measured from the traces and used to construct normalized amplitude histograms. The normalization procedure allowed the data from many animals to be pooled. For input from triceps sensory afferents onto different classes of motoneurons, all amplitudes were normalized to the average monosynaptic EPSP from triceps sensory afferents onto triceps motoneurons. This procedure corrected for the variability from individual to individual of the average monosynaptic projection from triceps sensory axons onto triceps motoneurons. For animals with regenerated dorsal roots, the procedure was particularly useful because it took into account the variability from one animal to another of the amount of regeneration of triceps sensory fibers.

If, for a particular animal, a class of sensory afferents did not regenerate, i.e., input was $<0.2 \mathrm{mV}$ on average, then input from this class of sensory afferents was excluded from further analysis. For example, if internal/external triceps sensory afferents made $<0.2 \mathrm{mV}$ input onto every class of motoneuron (Footnote $e$ in Table I), then for this experiment, only inputs from medial triceps sensory afferents were used.

At the end of a recording session, DR2 was cut close to the ganglion and drawn up into a suction electrode containing a concentrated solution of horseradish peroxidase (HRP). After 10 to $20 \mathrm{~min}$, the electrode was removed and the spinal cord was left in the perfusion bath at $14^{\circ} \mathrm{C}$ overnight. After fixation (1.5\% glutaraldehyde $+0.5 \%$ paraformaldehyde), the tissue was embedded in gelatin-albumin, and $50-\mu \mathrm{m}$ transverse sections were cut on a freezing microtome and reacted for HRP with diaminobenzidine (Frank et al., 1980).

In three animals, the second dorsal root ganglia on both the operated and control sides were also fixed in aldehyde and embedded in plastic. Serial sections $(5 \mu \mathrm{m})$ were cut and stained with Lee's basic fuchsin. The number of cells in each ganglion was determined by counting all visible neuronal nucleoli in every fifth section. Total counts were corrected with Konigsmark's modification of Abercrombie's factor (Konigsmark, 1970). The smallest observable nucleolar profile was taken as $1 \mu \mathrm{m}$, and the average nucleolar radius in each of the ganglia was $1.2 \mu \mathrm{m}$. These values gave a correction factor of approximately 0.7 .

In four normal frogs, numbers of triceps sensory axons were measured by recording impulses in the acutely cut dorsal root with a tightfitting suction electrode. The amplitude of an impulse in single afferents was determined by stretching the medial triceps muscle to activate stretch-sensitive axons and measuring the resulting signal in the dorsal root using the method of spike-triggered averaging. The stretch-activated sensory impulses were recorded en passant in the triceps nerve, and these impulses were used to trigger the averager (see Lichtman and Frank, 1984, for details). The amplitude of an average single sensory impulse in the dorsal root was then compared to the signal recorded in the root when all triceps sensory axons were activated simultaneously by electrical stimulation of the triceps nerves. The ratio of this latter signal to that of a single impulse is equal to the number of axons that are present both in the peripheral triceps nerves and in the dorsal root. This is the number of triceps sensory axons that have made both peripheral and central projections.

\section{Results}

Behavior. Immediately following dorsal root section, frogs failed to use their arms correctly during landing. Normally, both forelimbs are placed forward at the completion of a leap to catch the animal's body weight. After the dorsal root was cut or crushed, however, the affected limb was held rigidly adducted against the body; only the normal arm was used for supporting body weight. This behavior generally improved over the course of several months following the operation, although as shown in Table I, the final behavior was variable from individual to individual.

Arm withdrawal in response to pinch was rarely regained. Among 6 animals opcrated as tadpoles, only 2 responded normally. None of the 9 juvenile frogs whose roots had been cut regained sensation, but 4 of the 14 animals with crushed roots did withdraw their arms in response to pinch (see Table I). The behavioral recovery of these last 4 animals was correlated with the presence of a substantial number of sensory fibers within the dorsal columns (see below).

Anatomy. Sensory axons that had been cut or crushed in the dorsal root in either tadpoles or juvenile frogs regrew into the spinal cord and arborized extensively in the dorsal horn near their entry point into the spinal cord. The fibers terminated in two regions of the dorsal horn, forming a dorsal and a ventral neuropil (see Fig. 1). In normal animals the dorsal neuropil region is where cutaneous fibers terminate, whereas muscle sensory afferents arborize exclusively in the more ventral region 
TABLE I

Regeneration after DR2 interruption: Behavioral, anatomical, and physiological recovery

\begin{tabular}{|c|c|c|c|c|c|c|c|c|c|c|}
\hline \multirow{2}{*}{$\begin{array}{l}\text { Animal } \\
\text { No. }\end{array}$} & \multirow{2}{*}{$\begin{array}{l}\text { Initial } \\
\text { Stage }\end{array}$} & \multirow{2}{*}{$\begin{array}{l}\text { Recovery } \\
\text { Period }\end{array}$} & \multirow{2}{*}{$\begin{array}{c}\text { No. of } \\
\text { Correct } \\
\text { Landings }\end{array}$} & \multirow{2}{*}{$\begin{array}{l}\text { Sensation to } \\
\text { Pinch? }\end{array}$} & \multirow{2}{*}{$\begin{array}{c}\text { DR2 } \\
\text { Diameter }\end{array}$} & \multicolumn{2}{|c|}{$\begin{array}{l}\text { Labeled Dorsal } \\
\text { Axons }\end{array}$} & \multirow{2}{*}{$\begin{array}{c}\text { Average } \\
\text { Triceps } \\
\text { EPSP } \\
\text { Amplitude }^{b}\end{array}$} & \multirow{2}{*}{$\begin{array}{c}\text { Average } \\
\text { Non-triceps } \\
\text { EPSP } \\
\text { Amplitude }^{c}\end{array}$} & \multirow{2}{*}{$\begin{array}{l}\text { Specificity } \\
\text { Index }^{d}\end{array}$} \\
\hline & & & & & & Number & $\overline{\text { Length }^{a}}$ & & & \\
\hline & & months & & & $\begin{array}{c}\% \\
\text { normal }\end{array}$ & & $m m$ & & & \\
\hline \multicolumn{11}{|c|}{ DR2 Cut as Tadpole } \\
\hline $1^{e}$ & XIV & 6 & $4 / 10$ & Yes & 20 & $>40$ & $>4.0$ & $\begin{array}{c}0.21 \\
(5)^{f}\end{array}$ & $\begin{array}{c}0.01 \\
(6)^{g}\end{array}$ & 0.87 \\
\hline 2 & XVIII & 1 & $3 / 10$ & No & 25 & 4 & 2.0 & $\begin{array}{l}0.31 \\
(12)\end{array}$ & $\begin{array}{c}0.13 \\
(8)\end{array}$ & 0.59 \\
\hline 3 & XVIII & 1 & $9 / 10$ & Yes & & 10 & 2.0 & $\begin{array}{l}0.92 \\
(11)\end{array}$ & $\begin{array}{c}0.11 \\
(9)\end{array}$ & 0.88 \\
\hline 4 & XIX & 3 & & & & & & $\begin{array}{c}2.19 \\
(6)\end{array}$ & $\begin{array}{l}0.05 \\
(1)\end{array}$ & 0.98 \\
\hline 5 & XIX & 6.5 & & & & & & $\begin{array}{c}1.24 \\
(4)\end{array}$ & $\begin{array}{c}0.20 \\
(3)\end{array}$ & 0.84 \\
\hline 6 & XIX & 7 & & & & & & $\begin{array}{l}1.52 \\
(10)\end{array}$ & $\begin{array}{l}0.14 \\
(11)\end{array}$ & 0.91 \\
\hline $7^{e}$ & XXIV & 5 & $8 / 10$ & No & & 1 & 1.2 & $\begin{array}{c}0.30 \\
(7)\end{array}$ & $\begin{array}{c}0.02 \\
(6)\end{array}$ & 0.88 \\
\hline $8^{e}$ & XXIV & 5 & $5 / 10$ & No & 25 & 0 & 0.8 & $\begin{array}{c}0.34 \\
(6)\end{array}$ & $\begin{array}{c}0.07 \\
(4)\end{array}$ & 0.74 \\
\hline $9^{h}$ & XXII & 7 & $0 / 10$ & No & 15 & & & $\begin{array}{c}0.00 \\
(1)\end{array}$ & $\begin{array}{r}0.00 \\
(3)\end{array}$ & \\
\hline \multicolumn{11}{|c|}{ DR2 Cut as Juvenile } \\
\hline $10^{e}$ & & 4 & & No & & 2 & 1.4 & $\begin{array}{c}0.35 \\
(5)\end{array}$ & $\begin{array}{c}0.04 \\
(6)\end{array}$ & 0.92 \\
\hline $11^{e}$ & & 5 & $7 / 10$ & No & & 16 & 2.8 & $\begin{array}{c}0.96 \\
(4)\end{array}$ & $\begin{array}{l}0.06 \\
(8)\end{array}$ & 0.93 \\
\hline 12 & & 5 & $9 / 10$ & No & 50 & & & $\begin{array}{l}0.51 \\
(10)\end{array}$ & $\begin{array}{c}0.11 \\
(7)\end{array}$ & 0.78 \\
\hline 13 & & 6 & $7 / 10$ & No & & 17 & 1.8 & $\begin{array}{c}0.78 \\
(7)\end{array}$ & $\begin{array}{c}0.36 \\
(6)\end{array}$ & 0.54 \\
\hline 14 & & 6.5 & $7 / 8$ & No & & 10 & 3.6 & $\begin{array}{r}0.77 \\
(5)\end{array}$ & $\begin{array}{c}0.14 \\
(2)\end{array}$ & 0.82 \\
\hline 15 & & 7 & $2 / 8$ & No & & 1 & 1.0 & $\begin{array}{r}0.61 \\
(7)\end{array}$ & $\begin{array}{l}0.06 \\
(12)\end{array}$ & 0.91 \\
\hline $16^{e}$ & & 7 & $6 / 10$ & No & 15 & 2 & 1.6 & $\begin{array}{c}0.48 \\
(4)\end{array}$ & $\begin{array}{c}0.11 \\
(8)\end{array}$ & 0.59 \\
\hline $17^{e}$ & & 8 & $8 / 10$ & No & & 20 & 3.2 & $\begin{array}{c}0.36 \\
(6)\end{array}$ & $\begin{array}{c}0.05 \\
(4)\end{array}$ & 0.74 \\
\hline $18^{h}$ & & 6 & $0 / 10$ & No & & 2 & 1.2 & $\begin{array}{c}0.00 \\
(4)\end{array}$ & $\begin{array}{c}0.00 \\
(7)\end{array}$ & \\
\hline \multicolumn{11}{|c|}{ DR2 Crushed as Juvenile } \\
\hline 19 & & 4 & $4 / 10$ & No & & 6 & 1.2 & $\begin{array}{l}0.86 \\
(12)\end{array}$ & $\begin{array}{c}0.28 \\
(7)\end{array}$ & 0.68 \\
\hline 20 & & 4.5 & $10 / 10$ & No & 100 & 11 & 3.4 & $\begin{array}{l}0.89 \\
(12)\end{array}$ & $\begin{array}{c}0.14 \\
(7)\end{array}$ & 0.84 \\
\hline 21 & & 5 & $1 / 10$ & No & & 11 & 3.2 & $\begin{array}{l}0.77 \\
(13)\end{array}$ & $\begin{array}{c}0.03 \\
(8)\end{array}$ & 0.97 \\
\hline 22 & & 5 & $3 / 10$ & No & & & & $\begin{array}{r}0.61 \\
(9)\end{array}$ & $\begin{array}{c}0.11 \\
(9)\end{array}$ & 0.82 \\
\hline $23^{e}$ & & 5 & $3 / 10$ & No & & & & $\begin{array}{c}0.66 \\
(4)\end{array}$ & $\begin{array}{c}0.00 \\
(1)\end{array}$ & 1.00 \\
\hline 24 & & 5 & $7 / 10$ & No & & 14 & 2.0 & $\begin{array}{l}0.39 \\
(10)\end{array}$ & $\begin{array}{c}0.01 \\
(9)\end{array}$ & 0.98 \\
\hline 25 & & 6 & $9 / 10$ & No & 100 & 9 & 1.6 & $\begin{array}{l}0.64 \\
(15)\end{array}$ & $\begin{array}{c}0.53 \\
(1)\end{array}$ & 0.17 \\
\hline 26 & & 6 & $10 / 10$ & & 100 & 5 & 1.6 & $\begin{array}{l}0.43 \\
(10)\end{array}$ & $\begin{array}{c}0.17 \\
(7)\end{array}$ & 0.60 \\
\hline 27 & & 7 & $9 / 10$ & No & & 14 & 2.6 & $\begin{array}{l}0.48 \\
(12)\end{array}$ & $\begin{array}{c}0.20 \\
(9)\end{array}$ & 0.58 \\
\hline 28 & & 4 & $9 / 10$ & Yes & 100 & $>50$ & $>4.2$ & $\begin{array}{l}2.30 \\
(11)\end{array}$ & $\begin{array}{c}0.06 \\
(9)\end{array}$ & 0.97 \\
\hline 29 & & 5 & $3 / 10$ & Yes & & $>50$ & $>5.2$ & $\begin{array}{c}0.75 \\
(5)\end{array}$ & $\begin{array}{c}0.05 \\
(5)\end{array}$ & 0.94 \\
\hline
\end{tabular}


TABLE 1-Continued Regeneration after DR2 interruption: Behavioral, anatomical, and physiological recovery

\begin{tabular}{|c|c|c|c|c|c|c|c|c|c|c|}
\hline \multirow{2}{*}{$\begin{array}{l}\text { Animal } \\
\text { No. }\end{array}$} & \multirow{2}{*}{$\begin{array}{l}\text { Initial } \\
\text { Stage }\end{array}$} & \multirow{2}{*}{$\begin{array}{l}\text { Recovery } \\
\text { Period }\end{array}$} & \multirow{2}{*}{$\begin{array}{l}\text { No. of } \\
\text { Correct } \\
\text { Landings }\end{array}$} & \multirow{2}{*}{$\begin{array}{l}\text { Sensation to } \\
\text { Pinch? }\end{array}$} & \multirow{2}{*}{$\begin{array}{c}\text { DR2 } \\
\text { Diameter }\end{array}$} & \multicolumn{2}{|c|}{$\begin{array}{c}\text { Labeled Dorsal } \\
\text { Axons }\end{array}$} & \multirow{2}{*}{$\begin{array}{c}\text { Average } \\
\text { Triceps } \\
\text { EPSP } \\
\text { Amplitude }^{b}\end{array}$} & \multirow{2}{*}{$\begin{array}{c}\text { Average } \\
\text { Non-triceps } \\
\text { EPSP } \\
\text { Amplitude }^{c}\end{array}$} & \multirow{2}{*}{$\begin{array}{l}\text { Specificity } \\
\text { Index }^{d}\end{array}$} \\
\hline & & & & & & Number & Length $^{a}$ & & & \\
\hline & & \multicolumn{2}{|l|}{ months } & \multicolumn{3}{|c|}{$\begin{array}{c}\% \\
\text { normal }\end{array}$} & $m m$ & \multirow{2}{*}{\multicolumn{2}{|c|}{$m V$}} & \\
\hline \multicolumn{9}{|c|}{ DR2 Crushed as Juvenile } & & \\
\hline 30 & & 5 & $9 / 10$ & Yes & & $>50$ & $>5.0$ & $\begin{array}{c}1.02 \\
(4)\end{array}$ & $\begin{array}{c}0.03 \\
(3)\end{array}$ & 0.97 \\
\hline 31 & & 6 & $10 / 10$ & Yes & 100 & $>50$ & $>4.4$ & $\begin{array}{r}2.91 \\
(2)\end{array}$ & $\begin{array}{c}0.18 \\
(2)\end{array}$ & 0.94 \\
\hline $32^{h}$ & & 2 & $9 / 10$ & No & 20 & & & $\begin{array}{c}0.15 \\
(4)\end{array}$ & & \\
\hline
\end{tabular}

${ }^{a}$ The length is the rostrocaudal extent of HRP-labeled sensory axons in the dorsal columns.

${ }^{b}$ Average amplitude of monosynaptic EPSPs from triceps sensury afferents to triceps motoneurons.

${ }^{c}$ Average amplitude of monosynaptic EPSPs from triceps sensory afferents to subscapularis and pectoralis motoneurons.

${ }^{d}$ The specificity index is defined as 1-ratio, where the ratio is the average monosynaptic EPSP amplitude from triceps sensory afferents to

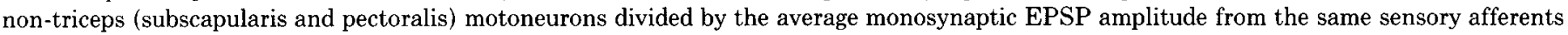
to triceps motoneurons.

"Intenal-external triceps sensory afferents did not regenerate to a significant extent (see "Materials and Methods").

t Numbers in parentheses are the number of triceps motoneurons sampled.

${ }^{g}$ Numbers in parentheses are the number of non-triceps (subscapularis and pectoralis) motoneurons sampled.

${ }^{h}$ Neither medial nor internal-external triceps sensory afferents regenerated to a significant extent. Data from these animals are not included in Figures 4, 5, or 6.

(Jhaveri and Frank, 1983). The formation of these same two neuropil regions after dorsal root regeneration suggested that sensory fibers might be terminating in appropriate target regions.

A feature of normal sensory projections that was usually not re-established after dorsal root regeneration was the long tract projection of sensory axons in the dorsal columns. Normally 3000 to 4000 myelinated axons from DR2 course longitudinally in these columns (Wilhelm and Coggeshall, 1981). Very few of these long tract fibers regenerated, however and the rostrocaudal extent of those few fibers that did project was less than normal (refer to Fig. 1). Counts of the number of labeled dorsal column fibers were taken at a distance of $0.5 \mathrm{~mm}$ from the DR2 entry zone. This is about the distance at which the density of regenerated sensory afferent arborizations in the neuropil was substantially diminished. Of five tadpoles with lesioned roots, four (animals \# 2, 3, 7, and 8 in Table I) had fewer than 11 dorsal column fibers labeled, with the total rostrocaudal extent of these fibers less than $2.5 \mathrm{~mm}$. In contrast, the one tadpole whose root was cut at stage XIV (animal \# 1 in Table I) had more than 40 labeled dorsal column fibers, with a longitudinal extent greater than $4.0 \mathrm{~mm}$.

Regrowth of fibers into the dorsal columns was also sparse or absent when the lesions (either cuts or crushes) were made in juvenile frogs. All 8 juveniles whose DR2s were cut and later labeled with HRP had fewer than 21 dorsal column fibers labeled, with the longitudinal extent less than $3.7 \mathrm{~mm}$. Of 11 juveniles whose DR2s were crushed, 7 had fewer than 15 labeled dorsal column fibers and a longitudinal projection of less than $3.5 \mathrm{~mm}$. In contrast, the other 4 frogs (animals \# 28, 29, 30, and 31 in Table I) had more than 50 labeled dorsal column axons which projected longitudinally for more than $4.2 \mathrm{~mm}$.

Except for the four animals specifically mentioned above, the small number of labeled sensory axons in the dorsal columns in animals with cut or crushed dorsal roots provided an internal control that sensory axons were severed by the crush procedure. If some sensory axons had not been severed, their axons would have been present in the dorsal columns.

The presence of a substantial number of dorsal column fibers in the other four frogs, as well as the stage XIV tadpole, was correlated with reproducible arm withdrawal in response to pinch. These observations raised the possiblity that the crushes were incomplete in the four frogs opcrated as juveniles; there- fore, the data from these experiments were excluded from further analysis. However, it is possible (and we think likely) that the DR2 crushes in this excluded group were actually complete. If so, it would suggest that dorsal column fiber regeneration can be more successful after crushing than after cutting the sensory root (see "Discussion").

Physiology. Functional synaptic connections were formed by regenerating sensory axons with spinal neurons. Stimulation of either cutaneous or muscle nerves in the periphery evoked synaptic potentials in brachial motoneurons (see Fig. 2). One measure of the specificity of these regenerated connections was that inputs from muscle sensory axons onto motoneurons were monosynaptic (average latency of only $5.7 \mathrm{msec}, n=229$ ), whereas inputs from cutaneous sensory axons onto the same motoneurons were mediated polysynaptically (average latencies were $14.5 \mathrm{msec}, n=150$ ) (see examples in Fig. 2). The corresponding latencies for normal animals in this study were 5.0 msec $(n=144)$ for muscle sensory inputs and $12.0 \mathrm{msec}$ ( $n=$ 106) for cutaneous inputs. Thus, muscle sensory axons re-form monosynaptic connections with motoneurons while cutaneous afferents do not, just as in normal animals.

Another measure of specificity of these regenerated connections was made by comparing the amplitudes of triceps EPSPs in triceps versus non-triceps motoneurons. In a normal frog, triceps sensory afferents project very differently to triceps and non-triceps motoneurons (Frank and Westerfield, 1982). Stimulation of triceps sensory afferents elicits larger monosynaptic EPSPs in triceps motoneurons than in subscapularis or pectoralis motoneurons. This normal, specific pattern of input is reestablished in animals with regenerated dorsal roots. Representative single traces illustrating this specificity are shown in Figure 3 , and the combined results from all animals with regenerated roots are shown in the histograms of synaptic potential amplitudes in Figure 4 . In frogs whose dorsal roots were cut during larval life, the monosynaptic input from triceps sensory axons was 6.6-fold larger, on average, in triceps motoneurons than in subscapularis or pectoralis motoneurons. Similarly, when the dorsal root was cut or crushed in juvenile frogs, EPSPs from regenerated triceps sensory axons were an average of 4 times larger in triceps than in these non-triceps motoneurons. This preference for triceps over non-triceps motoneurons was very similar whether the dorsal root had been cut or crushed. 


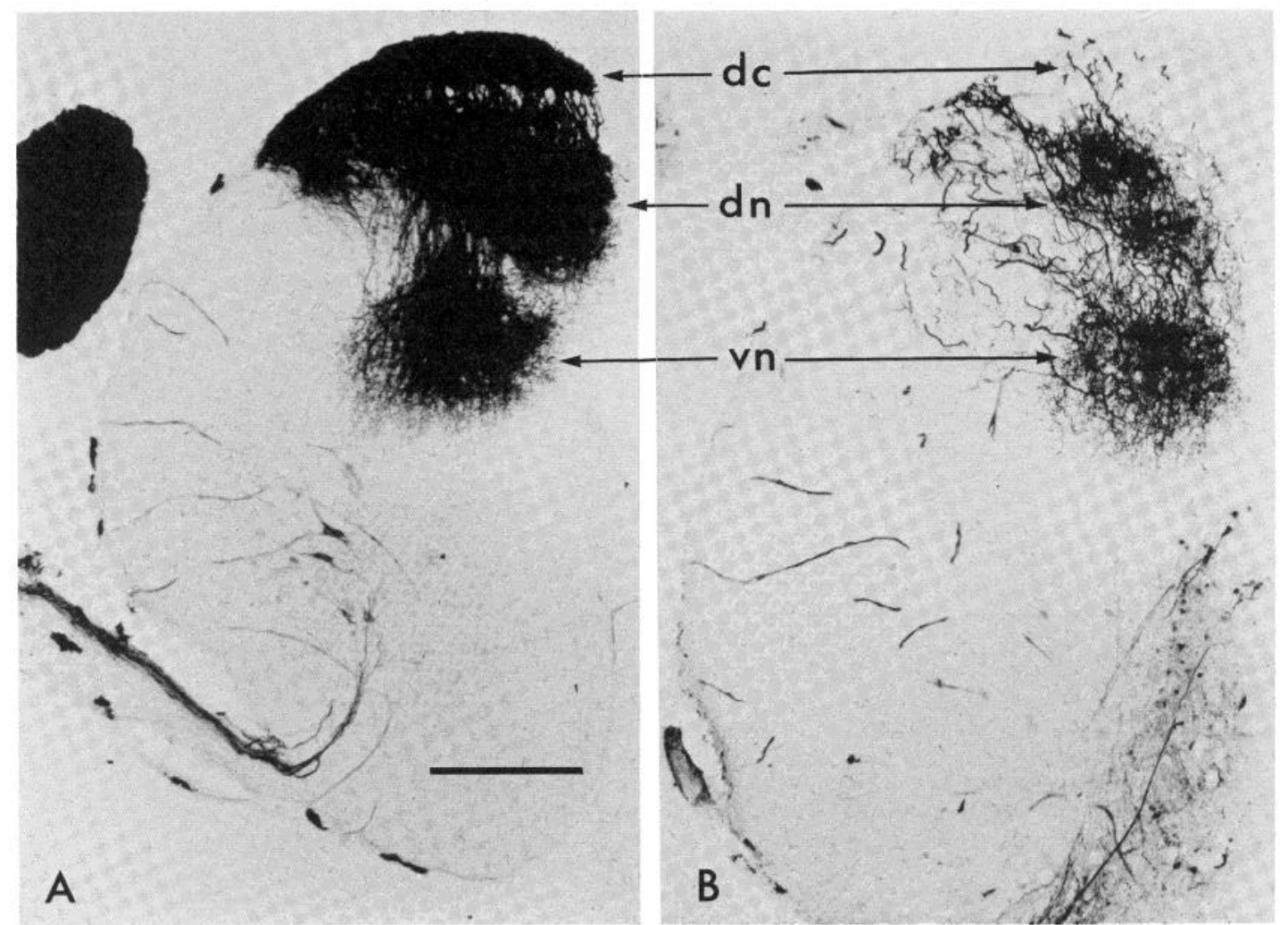

Figure 1. Projection of DR2 sensory afferents within the spinal cord. Sensory axons were labeled with HRP (diaminobenzidine reaction) applied to the cut dorsal root. Sections are just rostral or caudal to the DR2 entry zone. $A$, Normal juvenile. Sensory afferents project longitudinally through the dorsal columns $(d c)$ and terminate in two zones, the dorsal neuropil $(d n)$ and the ventral neuropil (vn). B, Juvenile frog with regenerated dorsal root. The root had been cut after metamorphosis several months earlier. Sensory afferents re-form a dorsal and ventral neuropil but make few long tract projections through the dorsal columns. Scale bar $=250 \mu \mathrm{m}$.
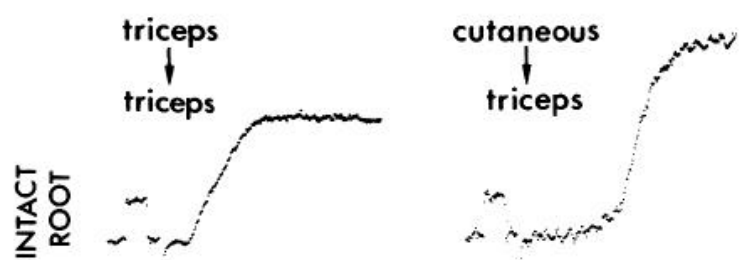

INTACT ROOT

REGENERATED ROOT
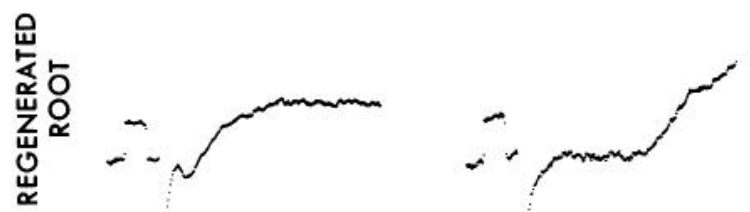

Figure 2. Cutaneous versus muscle sensory EPSPs in triceps motoneurons. In a normal juvenile (intact root), cutaneous afferent EPSPs (evoked by stimulation of the superior cutaneous branch of the radial nerve) in triceps motoneurons are polysynaptic (latency $>6.5 \mathrm{msec}$ ), whereas triceps muscle sensory EPSPs (evoked by stimulation of the triceps nerve) in triceps motoneurons are monosynaptic (latency $<6.5$ msec). Similarly, in an animal whose DR2 was cut as a juvenile (regenerated root), cutaneous afferents regenerate to make polysynaptic projections to triceps motoneurons, while triceps muscle sensory afferents re-form monosynaptic projections to triceps motoneurons. Calibration pulse $=0.5 \mathrm{mV}, 2 \mathrm{msec}$.

The amplitudes of triceps EPSPs were often smaller in the animals with regenerated roots, and a few triceps motoneurons received no triceps input. Cell counts of DRG2 in the frog whose root was cut at stage XIV (animal \# 1 in Table I)
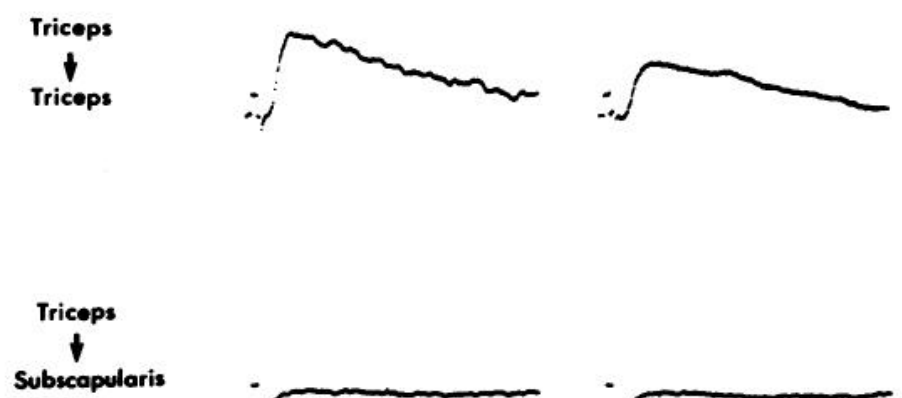

Subscapularis
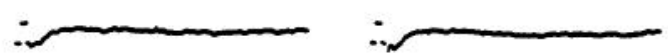

\section{Triceps \\ 1 \\ Pectoralis}

Figure 3. Monosynaptic EPSPs from triceps sensory afferents to triceps motoneurons are larger than those to non-triceps motoneurons in normal juveniles (intact root). This difference in projection strength is re-established in animals with regenerated dorsal roots. Calibration pulse $=0.5 \mathrm{mV}, 2 \mathrm{msec}$.

indicated that there were $60 \%$ fewer cells on the operated versus the control side (2135 versus 5199), so that lack of complete regeneration may have been due to axotomy-induced cell death in this case. Cell counts of regenerated and normal DRG2s in 


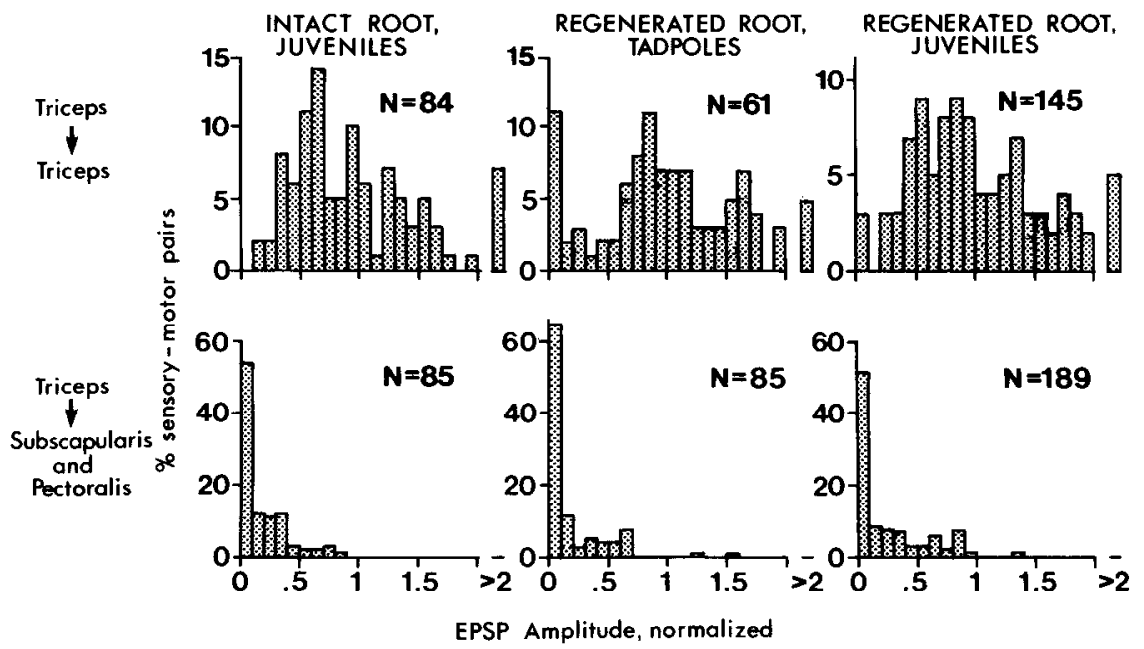

Figure 4. Normalized amplitude histograms of monosynaptic triceps sensory input to triceps and non triceps motoneurons (subscapularis and pectoralis combined). Monosynaptic EPSPs are defined as those with latencies $<6.5$ msec (see "Materials and Methods"). In juveniles with intact dorsal roots, monosynaptic input from triceps sensory afferents to triceps motoneurons is larger than that to non-triceps motoneurons. Similarly, in animals with DR2s cut as tadpoles, or with DR2s cut or crushed as juveniles, triceps sensory afferents regenerate to make stronger monosynaptic projections to triceps than to non-triceps motoneurons.

two of the juvenile frogs (animals \# 25 and 26 in Table I) were similar (4610 versus 4792 , and 5620 versus 5847 ), however; thus dorsal root lesions in juveniles probably do not result in a large amount of cell death.

Because the extent of regeneration varied from animal to animal, we computed a specificity index (SI) for each frog so that the specificity of regeneration could be compared more easily among animals with differing amounts of sensory regeneration. We first calculated the ratio of the average monosynaptic EPSP amplitude from triceps sensory afferents onto two classes of non-triceps motoneurons (subscapularis and pectoralis) divided by the average monosynaptic EPSP amplitude from the same sensory afferents to triceps motoneurons. The specificity index was then defined as 1 minus this ratio:

$$
S I=1-\frac{\text { triceps EPSPs in non-triceps motoneurons }}{\text { triceps EPSPs in triceps motoneurons }}
$$

This specificity index has the property that values close to 1 represent high levels of specificity (i.e., triceps sensory afferents project much more strongly to triceps than to non-triceps motoneurons) whereas values near 0 represent low levels of specificity (i.e., triceps inputs to triceps versus non-triceps motoneurons are similar).

Specificity indices are plotted in Figure 5 as a function of average monosynaptic triceps sensory input to triceps motoneurons, a measure of the extent of triceps afferent regeneration in the experimental animals. The results show that the specificity of triceps sensory regeneration was high, independent of the extent of regeneration. Specificity indices were always greater than zero, and only one frog had a specificity index less than 0.5 (for this frog, only one non-triceps motoneuron was sampled, thus the result has no statistical significance). The range ( $\pm 1 \mathrm{SD}$ around the mean) of specificity indices in both tadpoles and juveniles with regenerated dorsal roots overlapped substantially with that found in normal frogs ( 0.71 to 0.95 (roots cut as tadpoles) and 0.55 to 0.97 (roots cut or crushed as juveniles) compared wqith 0.73 to 0.95 (normal frogs)). Specificity was high even in cases where the extent of regeneration was the lowest. Furthermore, cutting or crushing the dorsal root made little difference in the specificity of regeneration (refer to Table I).

Normally there is a hierarchy in the strength of triceps sensory projections to several different types of non-triceps motoneurons. This is most easily seen in a plot of normalized amplitude ranges (mean $\pm 1 \mathrm{SD}$ ) for triceps input onto different

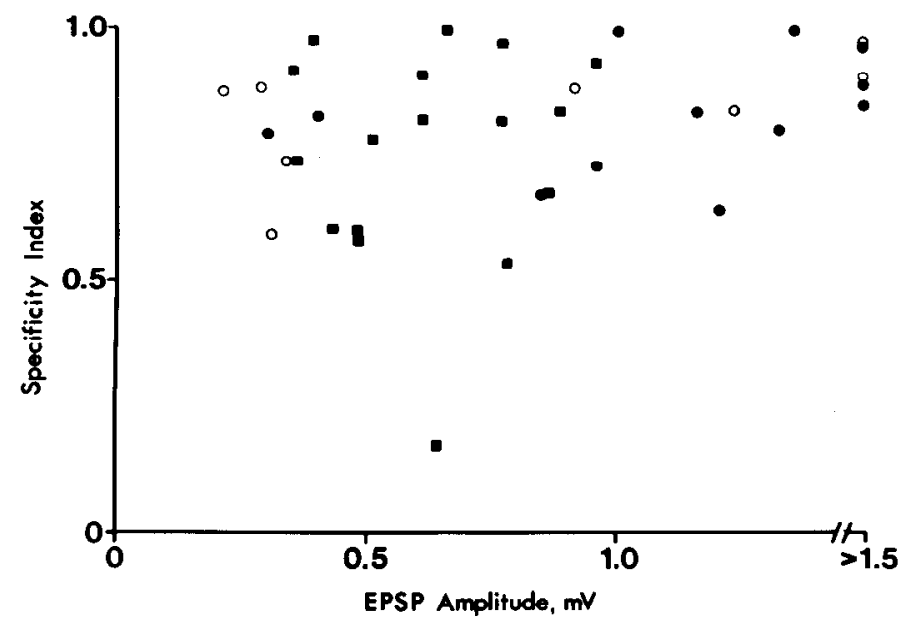

Figure 5. Specificity indices (see the text for definition) plotted as a function of the average monosynaptic triceps sensory input to triceps motoneurons (millivolts), a measure of the extent of regeneration. Each point represents the results (see Table I) from a single animal. The number of motoneurons sampled in each case is listed in Table I. $\bullet$ normal juveniles; $O$, DR2 cut as tadpole; $\square$, DR2 cut or crushed as juvenile. Specificity indices for most experimental animals are similar to those of normal juveniles

classes of motoneurons (Fig. 6). Triceps sensory afferents produce the largest EPSPs in triceps motoneurons, smaller EPSPs in ulnaris and radialis motoneurons, even smaller EPSPs in subscapularis motoneurons, and the smallest EPSPs in pectoralis motoneurons. This hierarchical input onto the four classes of motoneurons was re-established after regeneration. In normal frogs, the range of triceps input to triceps motoneurons falls above that of triceps input to ulnaris and radialis motoneurons, with no overlap. In animals with regenerated roots, triceps input onto triceps motoneurons is larger overall than triceps inputs onto ulnaris and radialis motoneurons, but the two ranges overlap considerably. Just as in normal juveniles, triceps sensory afferents in animals with regenerated DR2s project even more weakly to subscapularis motoneurons and most weakly of all to pectoralis motoneurons. In normal animals, the range of triceps input to subscapularis and pectoralis motoneurons falls below that of triceps input to triceps moto- 


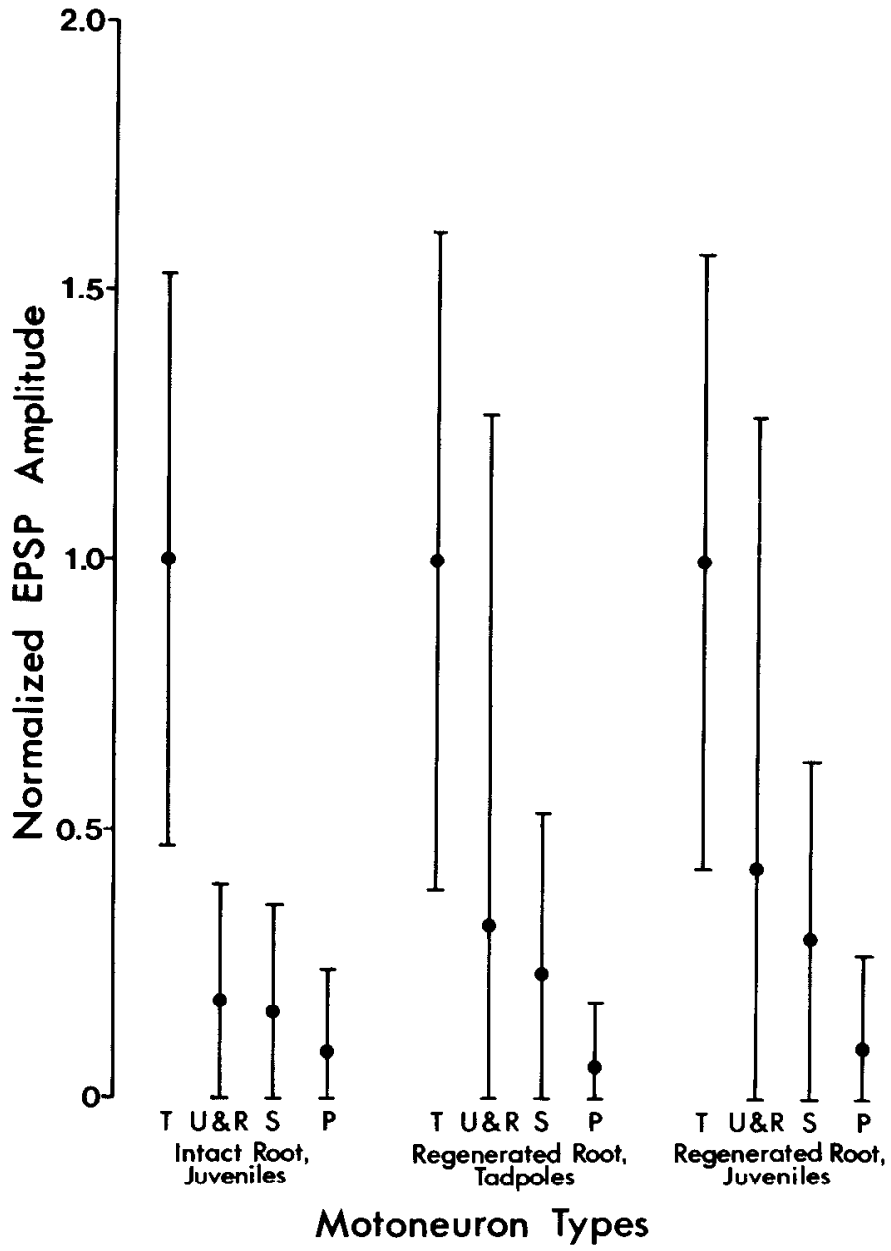

Figure 6. Normalized amplitude ranges (mean \pm SD) for monosynaptic triceps input to four classes of motoneurons: triceps $(T)$, ulnaris and radialis $(U \& R)$, subscapularis $(S)$, and pectoralis $(P)$. Differential triceps input is re-established in animals with DR2s cut as a tadpole or cut or crushed as a juvenile. Triceps motoneurons receive the largest input, followed by ulnaris and radialis, then subscapularis, and finally pectoralis, just as in the normal juvenile.

neurons, with no overlap. After regeneration, there is a small overlap between triceps input to triceps versus subscapularis motoneurons, but no overlap between input to triceps versus pectoralis motoneurons.

Number of triceps sensory axons. The interpretation that this synaptic specificity is the result of true axonal regeneration rather than de novo axonal elongation depends critically on the assumption that normal elongation has ceased in recently metamorphosed frogs, when the sensory axons were severed. We therefore tested this assumption directly, by counting the number of triceps sensory axons in the dorsal root in two adult frogs (at least 6 months postmetamorphic) and two young frogs (less than 2 weeks postmetamorphic). The counts were made electrophysiologically, by comparing the amplitude of a single sensory impulse recorded in DR2 to that of the compound action potential evoked by stimulation of the entire triceps nerve (see "Materials and Methods"). The two young frogs had 27 and 43 medial triceps axons, and both had 10 internalexternal triceps axons in the dorsal root, while the two adult frogs both had 28 medial axons and 6 and 10 internal-external axons. The number of triceps sensory axons in the dorsal root and hence presumably in the spinal cord is therefore already at its adult level shortly after metamorphosis. This implies that the synaptic connections we have demonstrated in juvenile frogs were the result of regeneration of triceps axons that were already in the spinal cord at the time they were interrupted in the dorsal root.

\section{Discussion}

The major finding from these studies is that sensory fibers can regenerate and re-form specific synaptic connections within the spinal cord after they are severed in the dorsal root. This specificity is shown in two ways. First, although both muscle and cutaneous sensory afferents regenerate, only muscle afferents make monosynaptic connections with brachial motoneurons. The cutaneous sensory input to motoneurons is polysynaptic, just as in normal animals. Second, following regeneration, the relative amplitudes of triceps monosynaptic EPSPs in different classes of motoneurons are the same as normal. Triceps sensory afferents form the strongest inputs to triceps motoneurons, weaker input to ulnaris and radialis motoneurons, even weaker input to subscapularis motoneurons, and weakest input to pectoralis motoneurons, the same pattern that exists in the normal frog.

When DR2 is cut in a late-stage tadpole, it may not be surprising that functional sensory-motor connections are reestablished, since the operations are performed at a time when triceps sensory afferents are normally still forming monosynaptic connections (Frank and Westerfield, 1983). Although sensory fibers probably have already grown into the spinal cord at the time the root is cut (Jhaveri and Frank, 1980; Frank and Westerfield, 1983), the "regeneration" in these animals may actually represent the initial process of synapse formation, although delayed somewhat by the lesion. However, when DR2 is cut or crushed in the postmetamorphic frog, triceps sensory afferent regeneration is also quite specific. Since these operations were performed after the number of triceps axons in the dorsal root had reached its adult level, true regeneration of functionally appropriate connections must be occurring in these animals.

Regenerating sensory fibers in this system usually do not reestablish their long projections in the dorsal columns. Normally, a dorsal root fiber projects for several spinal segments in the dorsal columns as well as arborizing locally in the dorsal horn. In contrast, regenerated fibers in experimental animals generally arborized only locally. Forehand and Farel (1982) and Stensaas (1983) have also noted the absence of long tract regeneration in the spinal cord of lower vertebrates. In adult mammals, long tract fibers also do not regenerate within the spinal cord (Lampert and Cressman, 1964; Gilson and Stensaas, 1974), although here even the amount of local arborization is usually quite small (David and Aguayo, 1981).

An intriguing observation is that dorsal column projections were present in four of the frogs after dorsal root crush, and these were the only animals that regained completely normal use of their arms. In these animals, triceps monosynaptic EPSPs were as large as normal, and the specificity of their reconnections with brachial motoneurons was high. Because we have no absolute guarantee that all of the sensory axons had been successfully disrupted, we have excluded these animals from our results. However, it will be interesting to see if regeneration is even better when sensory fibers are interrupted without severing the entire dorsal root.

Zakon and Capranica (1981) have reported that auditory fibers in the VIIIth nerve regenerate and reinnervate the cochlear nucleus of mature frogs. Binaural cells in the superior olivary nucleus normally have similar frequency sensitivities when tested in the two ears. After regeneration of one VIIIth nerve, input from the two sides was again well matched. Zakon and Capranica (1981) suggest that a probable explanation of these results is that regenerating fibers selectively reinnervate their former target cells, as we have observed here. However, 
since the pathway is disynaptic, they also raise the possibility that regenerating fibers might reinnervate the original target area randomly, the interneurons then rearranging their projections within the superior olive so that binaural cells acquire matched best frequencies.

Another well known example of regeneration within the CNS of lower vertebrates is the retinotectal pathway. Retinal ganglion axons can elongate over a relatively long distance within the CNS to re-form functionally appropriate connections within the tectum (Gaze and Jacobson, 1963; Gaze and Keating, 1970; Yoon, 1973). This system differs from the sensory-motor system in that retinal ganglion cells are continuously born, adding to the perimeter of the retina and sending new projections to the tectum (Straznicky and Gaze, 1971). Newborn cells in the adult must have the ability to grow for long distances within the CNS and form appropriate connections in the tectum if they are to be functional; therefore, cues for specific synapse formation must persist throughout adulthood. Perhaps these same cues are involved in specific retinotectal regeneration.

In contrast, in the sensory-motor system studied here, the major period of DRG cell birth is over before metamorphosis (Davis and Constantine-Paton, 1983), and the number of triceps sensory axons has already reached its adult level by this time. Nevertheless, after DR2 is cut or crushed in the juvenile frog, triceps sensory afferents regenerate to form the normal pattern of sensory-motor connections. Thus, even well after the period of normal synaptogenesis, cues for specific synapse formation persist in the CNS.

\section{References}

David, S., and A. J. Aguayo (1981) Axonal elongation into peripheral nervous system "bridges" after central nervous system injury in adult rats. Science 214: 931-933.

Davis, M. R., and M. Constantine-Paton (1983) Hyperplasia in the spinal sensory system of the frog. I. Plasticity in the most caudal dursal root ganglion. J. Comp. Neurol. 221: 444-452.

Ecker, A. (1889) The Anatomy of the Frog, G. Haslam (transl.), Clarendon Press, Oxford.

Forehand, C. J., and P. B. Farel (1982) Anatomical and behavioral recovery from the effects of spinal cord transection: Dependence on metamorphosis in anuaran larvae. J. Neurosci. 2: 654-662.

Frank, E., and M. Westerfield (1982) Synaptic organization of sensory and motor neurones innervating triceps brachii muscles in the bullfrog. J. Physiol. (Lond.) 324: 479-494.

Frank, E., and M. Westerfield (1983) Development of sensory-motor synapses in the spinal cord of the frog. J. Physiol. (Lond.) 343: 593610.

Frank, E., W. A. Harris, and M. B. Kennedy (1980) Lysophosphatidyl choline facilitates labelling of CNS projections with horseradish peroxidase. J. Neurosci. Methods 2: 183-189.

Frank, E., S. Jhaveri, and D. W. Y. Sah (1982) Regeneration of sensorymotor synapses in the spinal cord. Soc. Neurosci. Abstr. 8: 916.

Gaze, R. M., and M. Jacobson (1963) A study of the retinotectal projection during regeneration of the optic nerve in the frog. Proc. R. Soc. Lond. (Biol.) 157: 420-448.

Gaze, R. M., and M. J. Keating (1970) Further studies on the restoration of the contralateral retinotectal projection following regenera- tion of the optic nerve in the frog. Brain Res. $21: 183-195$.

Gearhart, J., M. L. Oster-Granite, and L. Guth (1979) Histological changes after transection of the spinal cord of fetal and neonatal mice. Exp. Neurol. 66: 1-15.

Gilson, B. C., and L. J. Stensaas (1974) Early axonal changes following lesions of the dorsal columns in rats. Cell Tissue Res. 149: 1-20.

Jhaveri, S., and E. Frank (1980) Morphological development of sensory axons and motoneurons in the brachial spinal cord of bullfrog tadpoles (Rana catesbeiana). Soc. Neurosci. Abstr. 6: 846.

Jhaveri, S., and E. Frank (1983) Central projections of the brachial nerve in bullfrogs: Muscle and cutaneous afferents project to different regions of the spinal cord. J. Comp. Neurol, 221: 304-312.

Konigsmark, B. W. (1970) Methods for counting of neurons. In Contemporary Research Methods in Neuroanatomy, W. J. H. Nauta and S. O. E. Ebbesson, eds., pp. 315-340, Springer-Verlag, New York.

Lampert, P., and M. Cressman (1964) Axonal regeneration in the dorsal columns of the spinal cord of adult rats. Lab. Invest. 13: 825839 .

Lichtman, J. W., and E. Frank (1984) Physiological evidence for specificity of synaptic connections between individual sensory and motor neurons in the brachial spinal cord of the bullfrog. J. Neurosci. 4: 1745-1753.

Liuzzi, F. J., and R. J. Lasek (1983) Regeneration of sensory and motor axons into the spinal cord of the adult frog. A study using dorsal to dorsal and ventral to dorsal root anastamoses. Soc. Neurosci. Abstr. 9: 695 .

Perkins, C. S., T. Carlstedt, K. Mizuno, and A. J. Aguayo (1980) Failure of regenerating dorsal root axons to regrow into the spinal cord. Can. J. Neurol. Sci. 7: 323.

Puchala, E., and W. F. Windle (1977) 'l'he possibility of structural and functional restitution after spinal cord injury. A review. Exp. Neurol. 55: $1-42$.

Richardson, P. M., U. M. McGuinness, and A. J. Aguayo (1980) Axons from CNS neurones regenerate into PNS grafts. Nature 284: 264265.

Richardson, P. M., U. M. McGuinness, and A. J. Aguayo (1982) Peripheral nerve autografts to the rat spinal cord: Studies with axonal tracing methods. Brain Res. 237: 147-162.

Stensaas, L. J. (1983) Regeneration in the spinal cord of the newt Notopthalmus (triturus) pyrrhogaster. In Spinal Cord Reconstruction, C. C. Kao, R. P. Bunge, and P. J. Reier, eds., Raven Press, New York.

Stensaas, L. J., P. R. Bruges, and K. W. Horch (1979) Regenerating dorsal root axons are blocked by spinal cord astrocytes. Soc. Neurosci. Abstr. 5: 684 .

Straznicky, K., and R. M. Gaze (1971) The growth of the retina in Xenopus laevis: An autoradiographic study. J. Embryol. Exp. Morphol. 26: 67-79.

Taylor, A. C., and J. J. Kollros (1946) Stages in the normal development of Rana pipiens larvae. Anat. Rec. 94: 7-23.

Westerfield, M., and E. Frank (1982) Specificity of electrical coupling among neurons innervating forelimb muscles of the adult bullfrog. J. Neurophysiol. 48: 904-913.

Wilhelm, G. B., and R. E. Coggeshall (1981) An electron microscopic analysis of the dorsal root in the frog. J. Comp. Neurol. 196: 421429.

Yoon, M. G. (1973) Retention of original topographic polarity by the 180 rotated tectal reimplant in young adult goldfish. J. Physiol. (Lond.) 233: 575-588.

Zakon, H., and R. R. Capranica (1981) Reformation of organized connections in the auditory system after regeneration of the eighth nerve. Science 213: 242-244. 